\title{
EXPERIMENTAL BEHAVIOUR OF STEEL TUBULAR COLUMNS FOR VARYING IN FILLED CONCRETE
}

\author{
P. SANGEETHA ${ }^{1}$, R. SENTHIL ${ }^{2}$
}

\begin{abstract}
This paper investigates the behaviour of axially-loaded tubular columns filled with M20 grade concrete and partially replaced concrete. The parameters varying in the study are slenderness ratio (13.27, $16.58 \& 19.9)$, and normal M20 grade concrete, partially replaced quarry dust and concrete debris. The effects of the various concrete mixes and composite action between the steel tube and the concrete core are studied and a graph visualizing the differences between the load carrying capacity and the axial deflection is plotted. Some of the performance indices like the Ductility Index (DI), Concrete Contribution Ratio (CCR), Confinement Index $(\theta)$ and Strength Index (SI) are also evaluated and compared amongst the CFST columns. From the results it has been noted that an increase in the L/D ratio decrease the behaviour of the composite columns irrespective of the in filled materials. The composite action was achieved in the CFST columns filled with partially replaced quarry dust and concrete debris when compared with hollow steel columns. The load carrying capacity of the CFST column increases by $32 \%$ compared with the hollow tubular columns.
\end{abstract}

Keywords: composite column, recycled aggregate, slenderness ratio, strength index, confinement index, CFST

\section{INTRODUCTION}

Concrete-filled steel tubular (CFST) columns have been used in different and varied applications, such as bridge piers which are continuously subjected to impact from traffic, columns that support storage tanks, railway decks, piles and columns in high-rise buildings. Because of the increased use of these types of composite columns, interest in the behaviour of these types of columns triggered

\footnotetext{
${ }^{1}$ Associate Prof., MS., PhD., SSN College of Engineering, Department of Civil Engineering, Kalavakkam, Chennai603 110, Tamilnadu , India, e-mail: sangeethap@ssn.edu.in

${ }^{2}$ Professor, ME., PhD., Anna University, Division of Structural Engineering, Guindy, Chennai - 600 025,Tamilnadu, India, e-mail:senthilr68@gmail.com
} 
many theoretical and experimental studies. Although CFST columns are suitable for tall buildings in seismic regions, their use has been limited due to a lack of information about the true strength and the in-elastic behaviour of CFST composite action. The main advantage of concrete in CFST is that it delays the local buckling of the tube wall and concrete itself, in its restrained state and also able to sustain higher stresses and strains when it is unrestrained. The concrete is subjected to a triaxial condition which results in increased strength. Research on CFT columns has been ongoing worldwide for many decades, with significant contributions saving has been made on tensile strength and ductility, while concrete members have the advantages of high compressive strength and fire resistance. Bo Wu et.al [1] have studied the severalnew proposed kinds of structural members containing demolished concrete with a distinctly larger size than conventional recycled aggregates. Bonet J.L. and Montalvá J.M [2] conducted experiments on thirty six rectangular and square tubular columns filled with normal and high strength concrete and subjected them to a nonconstant bending moment distribution with respect to the weak axis. Chithira K. and Baskar K [3],have carried out an experimental and numerical study on the behaviour of concrete filled circular steel tubular columns under eccentric load condition with and without shear connectors. Dong et.al [4] have investigated the structural behaviour of normal and recycled aggregate concrete filled steel tube (RACFT) columns externally strengthened with carbon fibre reinforced polymer (CFRP) sheets and subjected to axial loading. Ganesh Prabhu and Sundarraja [5] focused on experimentally and analytically investigating the suitability of carbon fibre reinforced polymer (CFRP) strip composites in strengthening CFST members under compression. Georgios Giakoumelis and Dennis Lam [6] studied the behaviour of circular concrete-filled steel tubes (CFT) with various concrete strengths under axial compression. Haedir and Jimmy [7] presented the external bonding of carbon fibre reinforced polymer (CFRP) sheets with epoxy resin effectively used to strengthen and repair concrete structures. Viveka and Shanmugavalli [8] assessed the feasibility of strengthening circular hollow steel tubular sections subjected to compression to develop or predict the suitable wrapping of FRP to enhance its structural behaviour.

\section{MATERIALS AND METHODS}

A total of twelve concrete filled tubular columns were tested under axial compression. The parameters varying in the study were the slenderness ratio (L/D) and in filled concrete. The dimensions of the specimens are shown in Table 1.The tubular pipes were made for three different lengths of $800 \mathrm{~mm}, 1000 \mathrm{~mm}, \& 1200 \mathrm{~mm}$. The tubular columns have yield strength and ultimate 
strength of $360 \mathrm{~N} / \mathrm{mm}^{2}$ and $550 \mathrm{~N} / \mathrm{mm}^{2}$, respectively, with a Poisson ratio of 0.3 . The tubular columns were filled with normal M20 grade concrete and partially replaced concrete. The coarse and fine aggregates of the M20 grade concrete were replaced by $30 \%$ concrete debris and $30 \%$ quarry dust. The compressive strengths of the normal concrete (NC), concrete with partially replaced concrete debris (CD), and concrete with partially repaced quarry dust (QD) were obtained as $22.32 \mathrm{~N} / \mathrm{mm}^{2}, 20.56 \mathrm{~N} / \mathrm{mm}^{2}$, and $18.96 \mathrm{~N} / \mathrm{mm}^{2}$ respectively. The specimens, test progress, and failed specimens are shown in Figs. 1 through 3

Table 1. Dimensions of the specimens

\begin{tabular}{|c|l|c|c|c|c|c|}
\hline $\begin{array}{c}\text { Sl. } \\
\text { No }\end{array}$ & \multicolumn{1}{|c|}{ Description } & $\begin{array}{c}\text { Specimen } \\
\text { ID }\end{array}$ & $\begin{array}{c}\mathrm{L} \\
(\mathrm{mm})\end{array}$ & $\begin{array}{c}\mathrm{D} \\
(\mathrm{mm})\end{array}$ & $\begin{array}{c}\mathrm{t} \\
(\mathrm{mm})\end{array}$ & (L / D ) \\
\hline 1 & Column without In filled Concrete & HS & 800 & 60.3 & 3.2 & 13.27 \\
\hline 2 & Column with Normal M20 Concrete & NC & 800 & 60.3 & 3.2 & 13.27 \\
\hline 3 & $\begin{array}{l}\text { Column with partially replaced debris } \\
\text { concrete }\end{array}$ & CD & 800 & 60.3 & 3.2 & 13.27 \\
\hline 4 & $\begin{array}{l}\text { Column with partially replaced } \\
\text { Quarry dust }\end{array}$ & QD & 800 & 60.3 & 3.2 & 13.27 \\
\hline 5 & Column without In filled Concrete & HS & 1000 & 60.3 & 3.2 & 16.58 \\
\hline 6 & Column with Normal M20 Concrete & NC & 1000 & 60.3 & 3.2 & 16.58 \\
\hline 7 & $\begin{array}{l}\text { Column with partially replaced } \\
\text { debris concrete }\end{array}$ & CD & 1000 & 60.3 & 3.2 & 16.58 \\
\hline 8 & $\begin{array}{l}\text { Column with partially replaced } \\
\text { Quarry dust }\end{array}$ & QD & 1000 & 60.3 & 3.2 & 16.58 \\
\hline 9 & Column without In filled Concrete & HS & 1200 & 60.3 & 3.2 & 19.90 \\
\hline 10 & Column with Normal M20 Concrete & NC & 1200 & 60.3 & 3.2 & 19.90 \\
\hline 11 & $\begin{array}{l}\text { Column with partially replaced } \\
\text { debris concrete }\end{array}$ & CD & 1200 & 60.3 & 3.2 & 19.90 \\
\hline 12 & $\begin{array}{l}\text { Column with partially replaced } \\
\text { Quarry dust }\end{array}$ & QD & 1200 & 60.3 & 3.2 & 19.90 \\
\hline
\end{tabular}




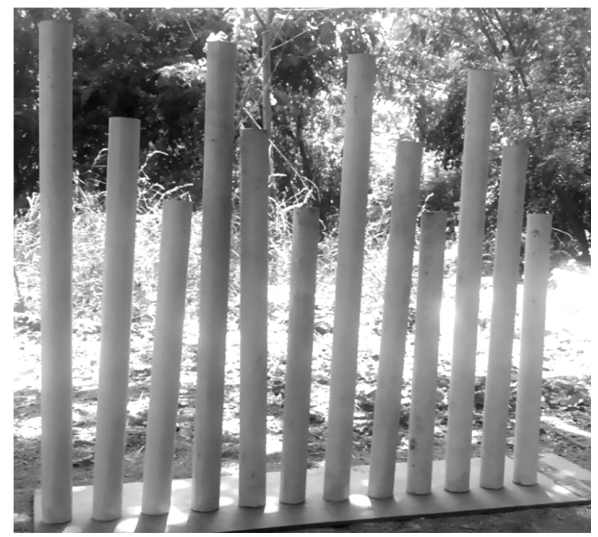

Fig. 1. Concrete filled steel tubular specimens

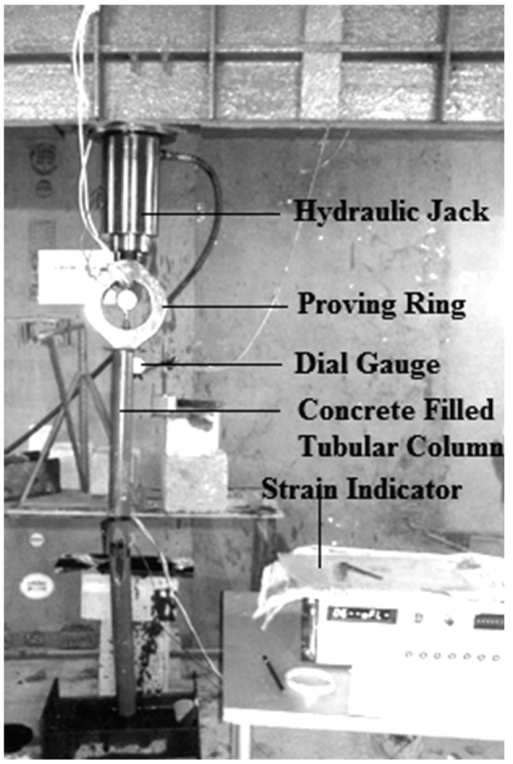

Fig. 2. Test in progress of CFST column specimen 


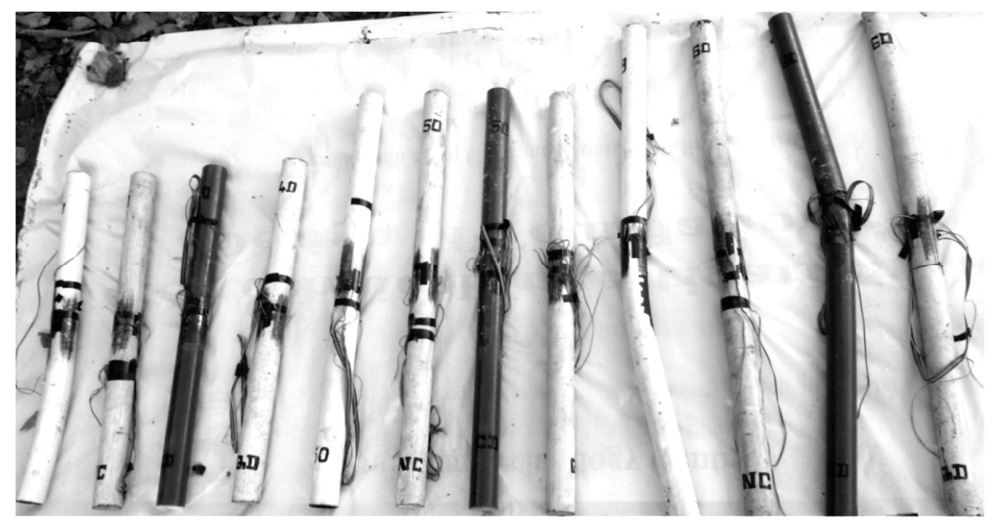

Fig. 3. Tested concrete filled tubular columns

\section{RESULT AND DISCUSSION}

\subsection{EFFECTS OF PARTIALLY REPLACED CONCRETE}

The behaviours of concrete filled tubular columns with partially replaced concrete (by quarry dust and concrete debris) in the standard M20 grade concrete were studied. The load- deflection behaviours of the composite column for the different slenderness ratios are shown in Figs. 4 through 6. The percentage increase in the deflection of the composite columns and the non - composite column (hollow column) is 25 to $32 \%$ for three different slenderness ratios of $13.27,16.58$, and 19.90. For the slenderness ratio of 13.27 , the percentage decrease in the deflection of the column with concrete debris (CD) and quarry dust (QD) is $14.3 \%$ and $19 \%$, when compared with normal M20 grade concrete filled column. The percentage decreases in the deflection for the slenderness ratio of 16.58 is $13.6 \%$ and $25 \%$ for change in concrete in the column from normal concrete to quarry dust. The percentage decrease in the deflection of the column with CD and QD is $4 \%$ and 12 $\%$ compared with the normal concrete column for the slenderness ratio of 19.90 . The load carrying capacity of the composite columns for different slenderness ratio was compared in the bar chart diagram and it is shown in Fig. 7. 


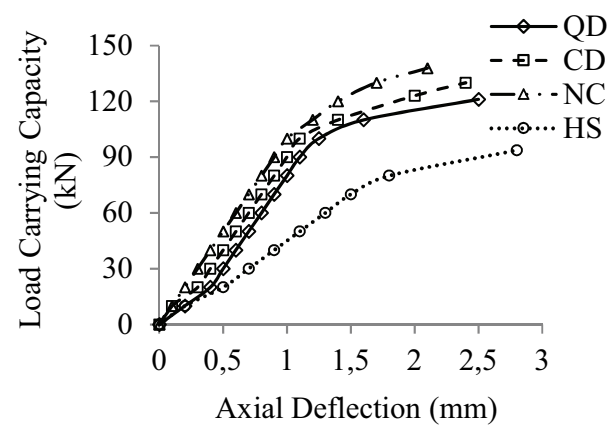

Fig. 4. Load-Deflection behaviour of CFST columns $(\mathrm{L} / \mathrm{D}=13.27)$

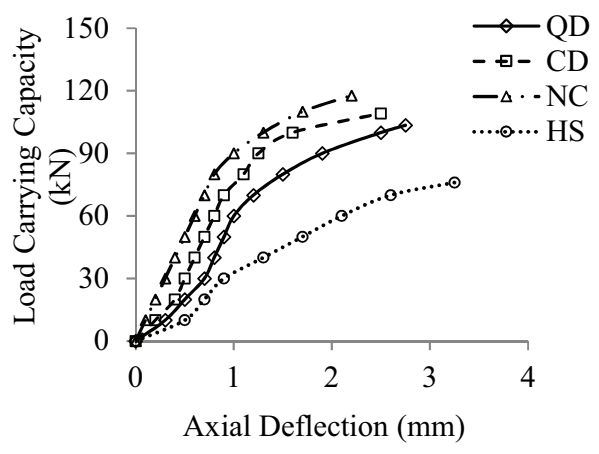

Fig. 5. Load-Deflection behaviour of CFST columns $(\mathrm{L} / \mathrm{D}=16.58)$

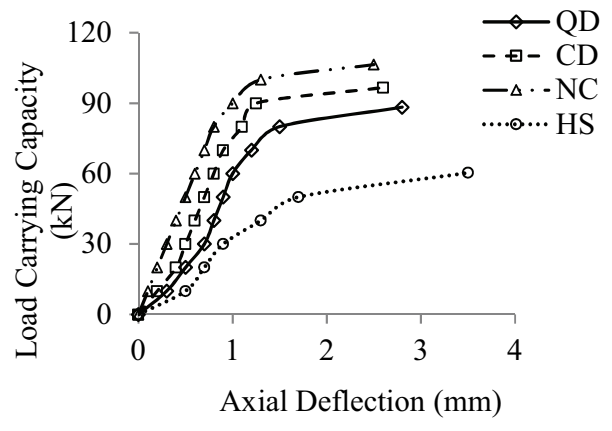

Fig. 6. Load-Deflection behaviour of CFST columns $(\mathrm{L} / \mathrm{D}=19.90)$

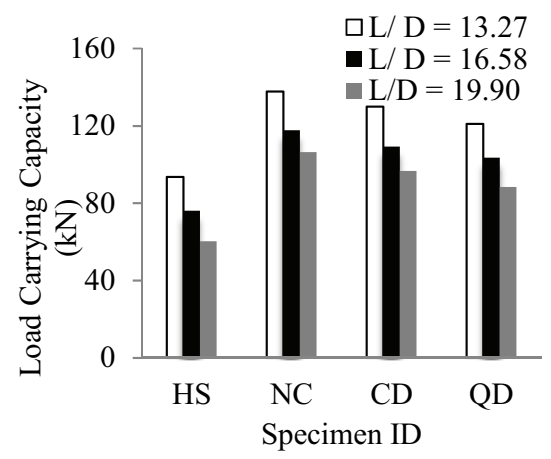

Fig. 7. Load carrying capacity of CFST columns

\subsection{CONCRETE CONFINEMENT RATIO AND STRENGTH INDEX}

To compare the ductility, strength enhancement and role of the concrete component in the CFST columns, some important parameters are defined and evaluated for the differently filled concrete samples (i.e normal concrete, concrete debris, and quarry dust); the Ductility Index (DI), Strength Index (SI), and Concrete Contribution Factor (CCR) respectively.

The concrete contribution ratio (CCR) is defined as the ratio between the maximum load of the composite column and the empty hollow steel column. 


$$
\mathrm{CCR}=\frac{\mathrm{N}_{\max (\text { exp })}}{\mathrm{N}_{\max (\text { hollow })}}
$$

As there are too many variables that affect this index, three combined variables which influence the main parameters affecting the test were selected: section behaviour (confinement index, $\theta$ ), relative slenderness $(\lambda)$, and the strength of concrete ' $f_{\mathrm{ck}}$ '. The confinement index is defined as:

$$
\theta=\frac{A_{s} f_{y}}{A_{c} f_{c k}}
$$

Figs. 8 and 9 show the compression between the CCR and the confinement index of the CFST columns. It was found that an increase in the $\mathrm{L} / \mathrm{D}$ ratio, increases the concrete confinement ratio, irrespective of the infilled concrete.

The strength index (SI) is defined as the ratio between the axial load carrying capacity of the CFST section to the sum of the strengths of the steel tube and the concrete combined.

$$
\text { SI } \quad=\frac{N_{\max }}{N_{p l} R_{d}}=\frac{N_{\max }}{A_{c} f_{c k}+A_{s} f_{y}}
$$

The increase in the L/D ratio, decreases the strength index of the CFST columns. Fig. 10 gives the variation of the strength index for concrete filled steel tubular specimens.

The ductility index (DI) is defined as the ratio between the deflection at the point in which the load carrying capacity dropped to $85 \%$ to the deflection at the maximum load.

$$
\text { DI } \quad=\frac{\delta(85 \% \text { of } \max )}{\delta(\max )}
$$

The increase in the DI is $10 \%$ for the columns filled with concrete debris than the column with normal concrete. The percentage increase in the DI for the column with quarry dust is $9 \%$ compared with normal concrete filled columns. The variations of the ductility index for the CFST columns are shown in Fig. 11. Table 2 gives the consolidated test results and calculated performance indices. 


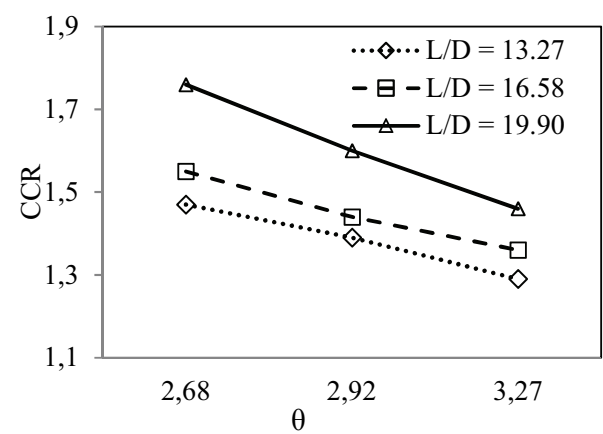

Fig. 8. Concrete contribution ratio versus confinement index

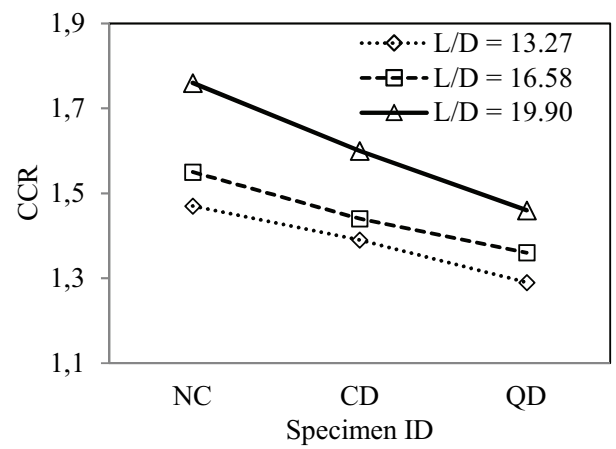

Fig. 9. Concrete contribution ratio of CFST columns

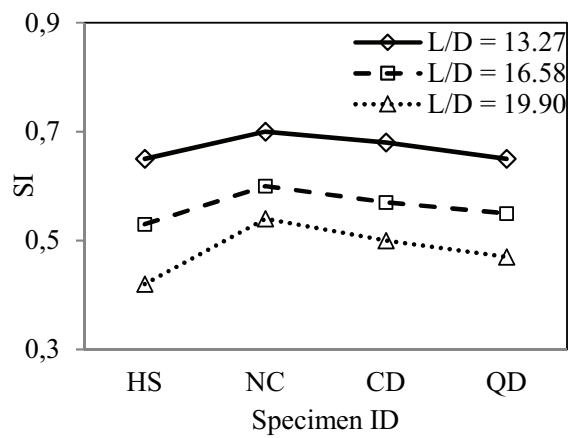

Fig. 10. Strength index of CFST columns

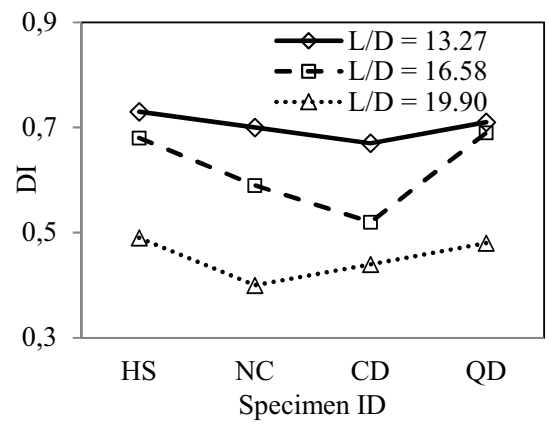

Fig. 11. Ductility index of CFST columns 
Table 2. Results of the CFST columns

\begin{tabular}{|c|c|c|c|c|c|c|c|c|c|c|c|}
\hline $\begin{array}{c}\text { Sl. } \\
\text { No }\end{array}$ & $\begin{array}{c}\text { Specimen } \\
\mathrm{ID}\end{array}$ & $\begin{array}{c}\mathrm{L} \\
\mathrm{mm}\end{array}$ & $\begin{array}{c}\mathrm{D} \\
\mathrm{mm}\end{array}$ & $\begin{array}{c}\mathrm{t} \\
\mathrm{mm}\end{array}$ & $\begin{array}{c}\mathrm{f}_{\mathrm{ck}} \\
\mathrm{N} / \mathrm{mm}^{2}\end{array}$ & $\begin{array}{c}\mathrm{L} / \mathrm{D} \\
\mathrm{N}_{\max (\exp )}\end{array}$ & $\mathrm{DI}$ & $\mathrm{CCR}$ & $\theta$ & $\mathrm{SI}$ \\
\hline 1 & $\mathrm{HS}$ & 800 & 60.3 & 3.2 & 0 & 13.27 & 93.69 & 0.64 & - & - & 0.65 \\
\hline 2 & $\mathrm{NC}$ & 800 & 60.3 & 3.2 & 23.50 & 13.27 & 137.83 & 0.67 & 1.47 & 2.68 & 0.70 \\
\hline 3 & $\mathrm{CD}$ & 800 & 60.3 & 3.2 & 21.56 & 13.27 & 129.98 & 0.58 & 1.39 & 2.92 & 0.68 \\
\hline 4 & $\mathrm{QD}$ & 800 & 60.3 & 3.2 & 19.23 & 13.27 & 121.06 & 0.50 & 1.29 & 3.27 & 0.65 \\
\hline 5 & $\mathrm{HS}$ & 1000 & 60.3 & 3.2 & 0 & 16.58 & 76.03 & 0.74 & - & - & 0.53 \\
\hline 6 & $\mathrm{NC}$ & 1000 & 60.3 & 3.2 & 23.50 & 16.58 & 117.72 & 0.59 & 1.55 & 2.68 & 0.60 \\
\hline 7 & $\mathrm{CD}$ & 1000 & 60.3 & 3.2 & 21.56 & 16.58 & 109.19 & 0.52 & 1.44 & 2.92 & 0.57 \\
\hline 8 & $\mathrm{QD}$ & 1000 & 60.3 & 3.2 & 19.23 & 16.58 & 103.50 & 0.69 & 1.36 & 3.27 & 0.55 \\
\hline 9 & $\mathrm{HS}$ & 1200 & 60.3 & 3.2 & 0 & 19.90 & 60.33 & 0.49 & - & - & 0.42 \\
\hline 10 & $\mathrm{NC}$ & 1200 & 60.3 & 3.2 & 23.50 & 19.90 & 106.44 & 0.40 & 1.76 & 2.68 & 0.54 \\
\hline 11 & $\mathrm{CD}$ & 1200 & 60.3 & 3.2 & 21.56 & 19.90 & 96.63 & 0.44 & 1.60 & 2.92 & 0.50 \\
\hline 12 & $\mathrm{QD}$ & 1200 & 60.3 & 3.2 & 19.23 & 19.90 & 88.29 & 0.48 & 1.46 & 3.27 & 0.47 \\
\hline
\end{tabular}

\section{Conclusions}

The results obtained from the tests on the composite columns presented in this paper allow the following conclusions to be drawn.

1. The use of concrete debris and quarry dust has resulted in improvement in the structural behaviour of the composite columns subjected to axial loading when compared with hollow steel columns.

2. Usage of recycled aggregate concrete in steel tubular columns is not only a waste utilisation technique, but also reduces costs of the in filled concrete.

3. The enhancement of strength in the case of the CFST columns depends on the compressive strength of the filled concrete and on the confinement effect.

4. The load carrying capacity of the CFST column increases by $32 \%$ comparing with hollow tubular columns irrespective of the in filled concrete. 


\section{SYMBOLS}

$\begin{array}{lll}\text { CFST } & - & \text { Concrete Filled Steel Tubular } \\ \text { HS } & - & \text { Hollow Column } \\ \text { NC } & - & \text { Normal Concrete } \\ \text { CD } & - & \text { Concrete Debris } \\ \text { QD } & - & \text { Quarry Dust } \\ \text { D } & - & \text { Outer diameter of the column } \\ \mathrm{t} & - & \text { Thickness of the steel tube } \\ \mathrm{f}_{\mathrm{ck}} & - & \text { Characteristic compressive strength of the concrete cube }\end{array}$

\section{REFERENCES}

1. Bo Wu,Yong Yang, "Cyclic testing of circular steel tubular columns filled with demolished concrete blocks and fresh concrete", Thin-Walled Structures 66: 50-61, 2013.

2. Bonet J. L., Montalvá J. M. "Ultimate capacity of rectangular concrete-filled steel tubular columns under unequal load eccentricities", Journal of Constructional Steel Research $68: 107-117,2014$.

3. Chithira K.., Baskar K, "Experimental and Numerical Investigation on Circular CFT Columns under Eccentric Load Condition with and without Shear Connectors ", International Journal of Earth Science and Engineering 05: 50-61, 2013.

4. Dong J.F.,Wang Q.Y., "Structural behaviour of recycled aggregate concrete filled steel tube columns strengthened by CFRP”, Engineering Structures 48: 532-542, 2012.

5. Ganesh Prabhu G., Sundarraja M.C., "Behaviour of concrete filled steel tubular (CFST) short columns externally reinforced using CFRP strips composite”, Construction and Building Materials 47: 1362-1371, 2013.

6. Georgios Giakoumelis, Dennis Lam, “Axial capacity of circular concrete-filled tube columns", Journal of Constructional Steel Research 60: 1049-1068, 2003.

7. Portolés J. M., Romero M. L., "Behaviour of steel tubular stub and slender columns filled with concrete using recycled aggregates", Journal of Constructional Steel Research 67: 623-633, 2011.

8. Zhong Tao , Lin-Hai Han, "Behaviour of fire-exposed concrete-filled steel tubular beam columns repaired with CFRP wraps", Thin-Walled Structures 45: 63-76, 2006. 


\section{List OF Figures AND TABLES}

Fig. 1. Concrete filled steel tubular specimens

Rys. 1. Stalowe próbki rurowe wypełnione betonem

Fig. 2. Test in progress of CFST column specimen

Rys. 2. Badanie próbki słupa CFST

Fig. 3. Tested concrete filled tubular columns

Rys. 3. Betonowe słupy rurowe poddane badaniu

Fig.4. Load-Deflection behaviour of CFST columns $(\mathrm{L} / \mathrm{D}=13.27)$

Rys. 4. Wskaźnik obciążenia i ugięcia słupów CFST $(\mathrm{L} / \mathrm{D}=13,27)$

Fig. 5. Load-Deflection behaviour of CFST columns $(\mathrm{L} / \mathrm{D}=16.58)$

Rys. 5. Wskaźnik obciążenia i ugięcia słupów $(\mathrm{L} / \mathrm{D}=16,58)$

Fig. 6. Load-Deflection behaviour of CFST columns $(\mathrm{L} / \mathrm{D}=19.90)$

Rys. 6. Wskaźnik obciążenia i ugięcia słupów $(\mathrm{L} / \mathrm{D}=19,90)$

Fig. 7. Load carrying capacity of CFST columns

Rys. 7. Nośność słupów CFST

Fig. 8. Concrete contribution ratio versus confinement index

Rys. 8. Współczynnik udziału betonu a wskaźnik zamknięcia

Fig. 9. Concrete contribution ratio of CFST columns

Rys. 9. Współczynnik udziału betonu w słupach CFST

Fig. 10. Strength index of CFST columns

Rys. 10. Wskaźnik wytrzymałości słupów CFST

Fig. 11. Ductility index of CFST columns

Rys. 11. Współczynnik plastyczności słupów CFST

Tab. 1. Dimensions of the specimens

Tab. 1. Wymiary próbek

Tab. 2. Results of the CFST columns

Tab. 2. Wyniki w zakresie słupów CFST 


\section{BADANIE DOŚWIADCZALNE STALOWYCH SLUPÓW RUROWYCH O RÓŻNYM WYPELNIENIU BETONEM}

Słowa kluczowe: słup zespolony, kruszywo pochodzące z recyklingu, wskaźnik smukłości, wskaźnik wytrzymałości, wskaźnik zamknięcia, CFST

\section{PODSUMOWANIE:}

Stalowe słupy rurowe wypełnione betonem (CFST) są wykorzystywane do różnorodnych zastosowań, takich jak filary mostów, które są stale narażone na oddziaływanie ruchu ulicznego, słupy obsługujące zbiorniki magazynowe, pokłady kolejowe, pale oraz słupy stosowane w wysokich budynkach. Ze względu na zwiększone wykorzystanie tego rodzaju słupów zespolonych, zainteresowanie zachowaniem tego typu słupów przyczyniło się do przeprowadzenia wielu badań teoretycznych i eksperymentalnych. Chociaż słupy CFST nadają się do wykorzystania w wysokich budynkach na obszarach sejsmicznych, ich zastosowanie zostało ograniczone z powodu braku informacji o prawdziwej wytrzymałości i nieelastycznym zachowaniu CFST. Główną zaletą betonu w CFST jest to, że opóźnia on lokalne wyboczenie ściany rury i samego betonu, w umiarkowanym stanie, a zatem jest w stanie utrzymać większe obciążenia i naprężenia niż w stanie nieumiarkowanym.

W niniejszej pracy zbadano zachowanie słupów rurowych obciążonych osiowo, wypełnionych betonem klasy M20 i częściowo zastąpionym betonem. Badaniu poddano łącznie 12 próbek, w celu zbadania zachowania stalowych słupów rurowych wypełnionych betonem przy różnym wypełnieniu. Parametry zróżnicowane w badaniu są współczynnikiem smukłości (13,27, 16,58 i 19,9) i betonem standardowej klasy M20, częściowo zastąpionym pyłem z kamieniołomu i odłamkami betonu. Badano wpływ różnych działań betonowych i kompozytowych w rurze stalowej i rdzeniu betonowym, a ponadto sporządzono wykres obciążenia i ugięcia osiowego. Niektóre wskaźniki wydajności, takie jak Wskaźnik Plastyczności (DI), Współczynnik Udziału Betonu (CCR), Wskaźnik Zamknięcia ( $\theta$ ) oraz Wskaźnik Wytrzymałości (SI) zostały również poddane ocenie i porównane z słupami CFST. Na podstawie wyników stwierdzono, że wzrost wskaźnika L/D ogranicza działanie słupów zespolonych, niezależnie od wypełnionych materiałów. Złożone działanie osiągnięto $w$ słupach CFST wypełnionych częściowo wymienionym pyłem $\mathrm{z}$ kamieniołomu i odłamkami betonu, w porównaniu z pustymi stalowymi słupami. Wykorzystanie odłamków betonu i pyłu z kamieniołomu doprowadziło do poprawy zachowania konstrukcji słupów zespolonych poddanych obciążeniu osiowemu, w porównaniu do pustych stalowych słupów. Zwiększenie wytrzymałości w przypadku słupów CFST zależy od wytrzymałości na ściskanie wypełnionego betonu oraz od wskaźnika zamknięcia. Nośność słupa CFST wzrasta o $32 \% \mathrm{w}$ porównaniu z pustymi słupami rurowymi, niezależnie od wypełnienia betonem. Wykorzystanie kruszywa pochodzącego $\mathrm{z}$ recyklingu $\mathrm{w}$ stalowych kolumnach rurowych jest nie tylko techniką utylizacji odpadów, lecz zmniejsza także koszt wypełnienia betonem. 